\title{
Knowledge, attitudes, and practices about coronavirus disease (COVID-19) among Birzeit University students: a cross-sectional study
}

\author{
Hani A. Naseef ${ }^{1}$ - Ni'meh A. Al-Shami ${ }^{1} \cdot$ Lilian S. Abu Hadba $^{1} \cdot$ Leen A. Humos ${ }^{1} \cdot$ Ruba N. Shaheen ${ }^{1}$. \\ Tanya T. Mitwasi ${ }^{1} \cdot$ Lina El-Khairy ${ }^{2}$
}

Received: 14 September 2020 / Accepted: 15 October 2021 / Published online: 8 November 2021

(c) The Author(s), under exclusive licence to Springer-Verlag GmbH Germany, part of Springer Nature 2021

\begin{abstract}
Aim COVID-19, the novel coronavirus, has been characterized as a pandemic, as it spreads all over the world and has so far infected more than 20 million worldwide. In Palestine, the first seven cases were documented on March 5 2020, followed by the declaration of the state of emergency. This study aimed to assess knowledge, attitudes and practices toward COVID-19 among Birzeit University students.

Subject and methods A cross-sectional study was carried out; a questionnaire was developed based on the WHO, CDC, and ECDC recommendations. The questionnaire was distributed online and filled out by Birzeit University students. Chi-square testing was performed to check for significant association between KAP (knowledge, attitude, and practices) and different socio-demographic variables. Binary logistic regression was performed to identify and control the confounding factors. Data were analyzed using SPSS (version 22).

Results A total of 665 students have completed the online questionnaire. The mean age was $20.55 \pm 3.069$ years. Multivariate analysis revealed that males, students from health professions and scientific faculties, and those with highly educated parents had manifested a good knowledge level (GKL) about COVID-19. With regard to students' practices, fewer negative practices were displayed by students from health professions faculty and the students living at the middle governorate of Palestine, compared to north, south, and Jerusalem dwellers. With regard to the practices, the vast majority of the participants showed a positive and very cautious practice in relation to the COVID-19 epidemic.

Conclusion Our results revealed that students had variable knowledge about COVID-19, and the vast majority depended on the official media briefs in Palestine as a source of information. With regard to practices, positive and cautious practices with regard to the COVID- 19 epidemic were carried out by the vast majority of participants.
\end{abstract}

Keywords Coronavirus disease-19 $\cdot$ COVID-19 $\cdot$ Knowledge $\cdot$ Awareness $\cdot$ Attitudes $\cdot$ Practices $\cdot$ Palestine $\cdot$ Birzeit University

\section{Introduction}

Coronaviruses are a large family of viruses which have been known to cause respiratory infections such as the Middle East respiratory syndrome (MERS), severe acute respiratory syndrome (SARS) and the coronavirus disease 19 (COVID-19)

Ni'meh A. Al-Shami

nemaashami86@gmail.com

1 Pharmacy Department, Faculty of Pharmacy, Nursing and Health Professions, Birzeit University, Birzeit, Palestine

2 Nutrition and Dietetics Department, Faculty of Pharmacy, Nursing and Health Professions, Birzeit University, Birzeit, Palestine
(WHO 2020a, b; Epidemiology Working Group for NCIP Epidemic Response, Chinese Center for Disease Control and Prevention 2020). COVID-19 was first discovered during an outbreak in Wuhan, China in December 2019 which led to thousands of deaths. Consequently, it spread widely throughout the world, with especially large outbreaks occurring in South Korea, Italy, Iran, the USA, and many other countries (World Health Organization 2020). By July 8, 2020, the virus had reached more than 150 countries, resulting in approximately 12 million infected people, among whom 5 million had recovered and 548,998 had died (WHO 2020a). These alarming levels of spread and severity of the disease have therefore raised the bar for the entire world to manage this stressful crisis 
and caused the World Health Organization to officially characterize COVID-19 as a pandemic (WHO/Europe 2020).

With regard to the symptoms of COVID-19, some infected people may not experience any symptoms, whereas others may have mild symptoms. Around $80 \%$ of patients recover without needing any special treatment, while one out of six patients develop more severe symptoms, including but not limited to difficulty in breathing; these patients are most likely to be elderly or with underlying medical conditions, such as high blood pressure, heart problems, or diabetes (ECDC 2020; Wang et al. 2020; Zhang et al. 2020b) Additionally, young people are not invincible against coronavirus; world data have shown that a large number of patients were young, among whom many needed hospitalization (Chen et al. 2020; Bialek et al. 2020; Escalera-Antezana et al. 2020).

On March 5 2020, the Palestinian authorities announced the first seven cases in the city of Bethlehem, which led to the declaration of a 30-day state of emergency. During this period, further preventative precautions such as quarantine and testing any suspected carriers were undertaken in an attempt to control this pandemic crisis without overwhelming the country's limited financial and healthcare resources. The unavailability of a definitive treatment or vaccine for COVID-19 at that time emphasized the importance of nonpharmaceutical protective and preventive measures as the only means of combating this disease.

Knowledge, attitudes, and practices with regard to COVID-19 among the Palestinian community are of immense importance and are critical for the community prevention/ control of this pandemic. The main objectives of this study were to evaluate the knowledge, attitude, and practices (KAP) regarding COVID-19 among students (undergraduate and postgraduate) at Birzeit University in Palestine.

This study aims to assess the relationship between students' different socio-demographic characteristics and their effects on their knowledge level, practices, and attitudes with regard to COVID-19. Moreover, this study evaluates the participants' opinions about the performance of the local authorities and their trusted source of information during this pandemic.

Evidence-based data from such studies could have an impact on policy decision-makers in the healthcare systems, and perhaps help in designing appropriate strategies to improve the awareness and attitudes with regard to COVID19 in order to facilitate managing the outbreak in Palestine.

\section{Material and methods}

\section{Study design and sample}

An observational analytical cross- sectional study was conducted among students (undergraduate and postgraduate) at Birzeit University in the occupied Palestinian territories between March and April 2020. The targeted respondents were all registered students from different majors (health and non-health professions) at the period of conducting the study, having an ID number and internet services. Any cases of duplication or fabrication in the inserted ID number were excluded.

The data were collected through an online distributed questionnaire between March 31 and April 10 2020, as this was considered the only feasible way of distributing the questionnaire during the forced lockdown. The questionnaire was designed and provided using Google Forms under the supervision of IT department personnel. The total population presented was 14,500 students, which is the total number of students registered at Birzeit University. The sample size was 375 as calculated online (Raosoft 2020) using the following equation with 95\% confidence level and 5\% error margin.

$n=N x /\left((N-1) E^{2}+x\right)$

where:

n Total sample size.

N Population size.

E Margin of error.

About 665 students completed the questionnaire as a selfselectiing sample after filling out their informed consent page online. The study was approved by the IRB committee at Faculty of Pharmacy, Nursing and Health Professions, Birzeit University with reference number BZU- PNH- 2006.

\section{Study tool}

The questionnaire was formed through a standardized methodology which includes the review of the literature information, group discussion, experts' evaluation, pilot study, and the validation of the final components of the questionnaire (Ishii et al. 2012; Arora et al. 2017). However, due to the worldwide lack of published literature regarding the evaluation of knowledge, attitudes, and practice (KAP) with regard to COVID-19 among various society districts, the information was obtained from a comprehensive literature review with regard to the evaluation of KAP toward MERS and SARS (Mbroh 2019; Lau et al. 2003; Bener and AlKhal 2004; Kim et al. 2016; Yang and Cho 2017; Al-Hazmi et al. 2018; Asaad et al. 2019; Goni et al. 2019), and from the WHO (WHO 2020c), Centers for Disease Control and Prevention (CDC n.d.), and European Center for Disease Prevention and Control (ECDC 2019) websites. 
The questionnaire components were reviewed and evaluated by the researchers' team in a series of meetings. The questionnaire was validated by four multidisciplinary experts panel with proven experience in epidemiology and research field, in order to obtain their input and their critical appraisals with regard to the questionnaire's content relevance and appropriateness. Thence, based on experts' feedback, some sectors of the questionnaire were excluded and re-phrasing of certain questions was considered. Furthermore, a pilot study was distributed among students of different faculties, in order to reveal any drawbacks presented in the questionnaire, where students were requested to complete the questionnaire and give their feedback concerning its clarity, construction, and relevance. Thence, based on students' assessment, some adjustments were made and the final draft was created in Arabic, then translated into English, and then underwent a final review.

The final questionnaire was composed of a short overview of the nature and purposes of the study, an assurance conerning the confidentiality of the respondents' responses, and the informed consent form. Then, in four sections to assess the socio-demographics, knowledge, attitudes, and practices of the participants, 45 questions were structured as both open- and closed-ended multiple choice questions. The socio-demographic section consisted of 13 questions regarding gender, age, marital status, major, study year, current place of residence, number of family members, whether any were aged over 60 , and parents' educational attainment and the nature of their work. The second section assessed the participants' knowledge of COVID-19 by asking 14 questions about the etiology, host, incubation period, transmission, prevention and control approaches, symptoms, risk group, mortality rate, and information sources. The answers were on the basis of yes and no, with an additional option of 'I don't know'. The third section assessed the students' attitudes towards COVID-19 using a set of ten questions with 'I agree', 'I don't agree', and 'I don't know' as answer options. This section measured agreement or otherwise with the following: invincibility against COVID-19, worry that a family member would get the disease, willingness to seek advice as needed, and preventive measures applied by the local authorities. The fourth section consisted of ten questions; nine of these assessed the students' practice with regard to COVID-19 and the tenth their smoking habits. The questions evaluated the preventive measures taken at the individual level including: self-hygiene, proper coughing or sneezing methods, wearing face masks, keeping a safe distance, limiting presence in public places, limiting travelling between different governorates, and whether they supplied their houses with antipyretics, necessary medications, vitamins, and nutritional supplements. The answers were 'frequently', 'always', 'often', 'rarely', and 'never'.

\section{Statistical analysis}

Descriptive statistics were performed to present data; a knowledge scale was developed from the 13 questions that identify the participants' knowledge about the virus, its symptoms, and how to prevent it, with internal consistency (Cronbach $\alpha=0.577$ ). Recoding for questions with more than one answer was done, then counting for the correct answers was performed within 32 items; one score was given for each. A scale was developed and recoded into acceptable knowledge level (AKL), scoring less than 26, and good knowledge level (GKL), scoring 26 to 32 . Another scale was developed for participants' practices; recoding for negative items was performed, a count for the positive statements within ten items was done, scored, and recoded into more positive practices ( 8 to 10 positives) or less positive ones (less than 8).

Chi-square testing with $95 \%$ confidence interval was performed to identify the socio-demographic variables associated with the knowledge and practice scales. Then a third Chi-square test with 95\% confidence interval was performed to assess the association between the knowledge level of respondents and their attitudes.

Binary logistic regression analysis was performed to establish the association between knowledge level and more positive practices with the variables that were identified as significant in the bivariate analysis, and to identify and control the confounding factors. All data were analyzed using the Statistical Package for Social Sciences (IBM SPSS Statistics 22).

\section{Results}

\section{Socio-demographic characteristics}

A total of 665 students completed the online questionnaire. The mean age was $20.55 \pm 3.069$ years, and 488 (73.4\%) were females. One hundred and seventy-six $(26.5 \%)$ of the students were from the pharmacy, nursing, and health professions faculty, and the remainder were from non-medical majors. Three hundred and seventy-nine $(59.7 \%)$ of the students resided in the middle of the West Bank, with 333 (50.1\%) being city residents. More than half of the students $(n=357,53.7 \%)$ were part of a big family consisting of more than six members, and $126(18.9 \%)$ in families which included members over the age of 60 . Additionally, $455(68.5 \%)$ of the students had at least one parent who had completed a diploma or higher education, with less than 5\% of them working in the health sector (Table 1). 


\section{Knowledge}

Out of 665 respondents, 495 (74.4\%) rated their own knowledge level regarding COVID-19 as good to very good; however, data analysis revealed that only 275 (41.4\%) actually had good knowledge level (GKL), whereas 390 (58.6\%) had acceptable knowledge level (AKL).

In total, $97.6 \%$ of respondents knew that COVID-19 is a viral infection that affects the respiratory tract system, $95.8 \%$ acknowledged that the median incubation period is between 2-14 day,s and $92.3 \%$ responded that it's a curable disease. However, only $46.6 \%$ recognized that bats are considered the original host for COVID-19.

Respondents' answers concerning COVID-19 transmission approaches revealed acknowledging sneezing or coughing respiratory droplets, touching face, eyes, nose, and mouth with contaminated hands, direct contact with patients, and contact with contaminated surfaces as methods of transmission, with percentages of $92.3 \%, 89.6 \%, 87.2 \%$, and $78.5 \%$ respectively. Furthermore, $91.6 \%$ of respondents knew that approaching pets is not a method for COVID-19 transmission.

Concerning COVID-19 symptoms, fever and dry cough were stated in more than $90 \%$ of participants' responses, whereas only $56.5 \%$ recognized general fatigue as a symptom, and $30.4 \%$ believed improperly that flu-like symptoms and nasal congestion were symptoms.

When asked about COVID-19 high-risk groups, over 90\% of respondents mentioned the elderly, patients with chronic diseases, and immune-compromised patients, while only $12 \%$ acknowledged that severe obesity is also considered a high-risk category.

As for COVID-19 prevention methods, drinking hot beverages and eating garlic, onions, and pickles were wrongly believed to be the optimal preventive approaches by $44.2 \%$ and $15.3 \%$ of the answers respectively (Table 2). Furthermore, $12.9 \%$ of participants believed that antibiotics are an optimal method for preventing COVID-19 infection, which is not proven at the time of conducting the study. On the other hand, the majority of the participants $(91.1 \%)$ believed that personal hygiene is an optimal method for preventing COVID-19 infection.

The official media outlets in Palestine (Ministry of Health website and government spokesperson) were the major sources of information about COVID-19 for $79.1 \%$ of the participants. A significant percentage $(69.6 \%)$ of the respondents reported scientific resources as a source of information, followed by media and the social media $(65.1 \%$ and $46.8 \%$ respectively) (Fig. 1).

As depicted in Table 3, logistic regression analysis results affirmed that students' extent of knowledge regarding COVID-19 is significantly related to their gender; females manifested lower knowledge levels compared to males
$(\mathrm{OR}=0.588, p=0.01)$. Regarding major specialty, a higher knowledge level of COVID-19 was manifested in scientific faculties $(\mathrm{OR}=1.841, p=0.004)$ and health professions faculties $(\mathrm{OR}=3.462, p<0.001)$ in comparison to literary faculties. Additionally, significant results were obtained with year progression; where students in their 4th year of studying or more were more likely to have GKL $(\mathrm{OR}=5.562$, $p<0.001)$, then 2 nd year students $(\mathrm{OR}=2.717, p<0.001)$ and 3rd year $(\mathrm{OR}=2.249, p=0.003)$ compared to 1 st year students. As for place of residency, results showed that refugee camps residents were the least likely to have GKL $(\mathrm{OR}=0.235, p=0.016)$ compared to city citizens. With regards to parental factors, students with both parents having higher educational attainment were more likely to have GKL $(\mathrm{OR}=1.931, p=0.013)$ compared to their counterparts, whilst students whose mothers worked in non-health related jobs or were unemployed were less likely to have GKL compared to health sector employees $(\mathrm{OR}=0.332$, $p=0.03$ and $\mathrm{OR}=0.345, p=0.04$ respectively).

\section{Attitudes}

As seen in Table 4, a higher percentage of respondents $(90.7 \%)$ were worried that a family member would get COVID-19; $84.1 \%$ of them remarkably thought that COVID19 preventative measures should be applied by everyone regardless of their status. In addition, $96.2 \%$ of the participants would seek assistance from the responsible authorities if they or a family member develops symptoms of COVID19. As for the practices applied by the government, $96.5 \%$ of respondents considered that the preventative measures taken by the Palestinian government at the beginning were sufficient and done in a timely manner.

Table 5 shows that although more than $90 \%$ of respondents were worried that a family member might get COVID19 , students with GKL were found to be significantly less likely to be worried $(8.7 \%, p=0.007)$. They believed that preventative measures should not be practiced solely by older adults and groups most at risk $(91.3 \%, p<0.001)$ in comparison to students with AKL (4.6\% and $79.0 \%$ respectively). Likewise, participants with GKL were less likely to consider themselves invincible from COVID-19 (56.7\%, $p<0.001)$ than those with AKL (34.4\%). Students with GKL were significantly more likely to believe that the attempts of the local authorities will not succeed in curbing the spread of COVID 19 (19.3\%) and that they did not have sufficient tools to deal with the pandemic (66.5\%) as compared to students with AKL (12.6\% and 54.9\% respectively). In addition, students with GKL were significantly more likely to believe that the preventive measures taken by the Palestinian government were neither early nor sufficient (54.9\% and 38.2\%) than students with AKL (52.3\% and 33.3\% respectively). 
Table 1 Socio-demographic characteristics of study participants $(n=655)$

\begin{tabular}{|c|c|c|}
\hline \multicolumn{2}{|l|}{ Socio-demographic characteristics } & \multirow{2}{*}{$\begin{array}{c}\text { No.: } n(\%) \\
177(26.6)\end{array}$} \\
\hline Gender & Male & \\
\hline & Female & $488(73.4)$ \\
\hline \multirow[t]{2}{*}{ Marital status } & Single & $622(93.5)$ \\
\hline & Married & $43(6.5)$ \\
\hline \multirow[t]{8}{*}{ Major } & Arts & $109(16.4)$ \\
\hline & Business and Economics & $112(16.8)$ \\
\hline & Science & $53(8.0)$ \\
\hline & Law and Public Administration & $33(5.0)$ \\
\hline & Pharmacy, Nursing and Health Professions & $176(26.5)$ \\
\hline & Education & $12(1.8)$ \\
\hline & Engineering & $167(25.1)$ \\
\hline & Arts, Music and Design & $3(0.5)$ \\
\hline \multirow[t]{5}{*}{ Study year } & First & $174(26.2)$ \\
\hline & Second & $169(25.4)$ \\
\hline & Third & $141(21.2)$ \\
\hline & Fourth or more & $146(22.0)$ \\
\hline & Postgraduate & $35(5.3)$ \\
\hline \multirow[t]{4}{*}{ Governorate } & Jerusalem and the occupied Palestinian territory & $140(21.1)$ \\
\hline & North of the WB & $71(10.7)$ \\
\hline & Middle of the WB & $397(59.7)$ \\
\hline & South of the WB & $57(8.6)$ \\
\hline \multirow[t]{3}{*}{ Place of residency } & City & $333(50.1)$ \\
\hline & Village & $307(46.2)$ \\
\hline & Refugee camps & $25(3.8)$ \\
\hline \multirow[t]{3}{*}{ Parents completed diploma or higher educational level } & None & $210(31.5)$ \\
\hline & One of them & $186(28.0)$ \\
\hline & Both & $269(40.5)$ \\
\hline \multirow[t]{5}{*}{ Mother's work } & Health sector & $25(3.8)$ \\
\hline & Education sector & $138(20.8)$ \\
\hline & Office jobs & $30(4.5)$ \\
\hline & Housewife & $426(64.1)$ \\
\hline & Other & $46(6.9)$ \\
\hline \multirow[t]{5}{*}{ Father's work } & Health sector & $34(5.1)$ \\
\hline & Education sector & $88(13.2)$ \\
\hline & Office jobs & $101(15.2)$ \\
\hline & Unemployed & $39(5.9)$ \\
\hline & Other & $403(60.6)$ \\
\hline \multirow[t]{2}{*}{ Number of family members } & Six or less & $308(46.3)$ \\
\hline & More than six & $357(53.7)$ \\
\hline \multirow[t]{2}{*}{ Including a family member over the age of 60} & Yes & $126(18.9)$ \\
\hline & No & $539(81.1)$ \\
\hline \multirow[t]{2}{*}{ Smoking habits } & Smoker & $106(15.9)$ \\
\hline & Non- smoker & $559(84.1)$ \\
\hline \multirow[t]{5}{*}{ Students' rating of their knowledge with regard to COVID-19 } & Very good & $173(26.0)$ \\
\hline & Good & $322(48.4)$ \\
\hline & Acceptable & $149(22.4)$ \\
\hline & Weak & $18(2.8)$ \\
\hline & Do not care & $3(0.5)$ \\
\hline
\end{tabular}


Table 2 Students' knowledge about COVID-19

\begin{tabular}{|c|c|c|c|}
\hline Statement & Yes: $n(\%)$ & No: $n(\%)$ & Don’t know: $n(\%)$ \\
\hline COVID-19 is an infectious viral disease that affects the respiratory system? & $649(97.6)$ & $7(1.1)$ & $9(1.4)$ \\
\hline Bats are considered the original host of COVID-19 infections? & $310(46.6)$ & $144(21.7)$ & $211(31.7)$ \\
\hline Is COVID-19 transmitted by touching and approaching pets? & $56(8.4)$ & $609(91.6)$ & \\
\hline Is COVID-19 transmitted by direct contact with patients? & $580(87.2)$ & $85(12.8)$ & \\
\hline Is COVID-19 subject to airborne transmission? & $142(21.4)$ & $523(78.6)$ & \\
\hline Is COVID-19 transmitted through respiratory droplets from sneezing or coughing? & $614(92.3)$ & $51(7.7)$ & \\
\hline Is COVID-19 transmitted by contact with contaminated surfaces? & $522(78.5)$ & $143(21.5)$ & \\
\hline Is COVID-19 transmitted by touching the face, eyes, nose, and mouth with contaminated hands? & $596(89.6)$ & $69(10.4)$ & \\
\hline The median incubation period for COVID-19 is (2-14) days? & $637(95.8)$ & $14(2.1)$ & $14(2.1)$ \\
\hline Sore throat is a symptom of COVID-19 & $454(68.3)$ & $211(31.7)$ & \\
\hline Fever is a symptom of COVID-19 & $602(90.5)$ & $63(9.5)$ & \\
\hline Productive cough is a symptom of COVID-19 & $77(11.6)$ & $588(88.4)$ & \\
\hline Dry cough is a symptom of COVID-19 & $605(91.0)$ & $60(9.0)$ & \\
\hline General fatigue is a symptom of COVID-19 & $376(56.5)$ & $289(43.5)$ & \\
\hline Flu and nasal congestion is a symptom of COVID-19 & $202(30.4)$ & $463(69.6)$ & \\
\hline All people infected will develop symptoms of COVID-19 & $69(10.4)$ & $538(80.9)$ & $58(8.7)$ \\
\hline $\begin{array}{l}\text { A negative primary examination test result of a person suspected of having COVID-19 eliminates } \\
\text { the need for quarantine for that person }\end{array}$ & $51(7.7)$ & $604(90.8)$ & $10(1.5)$ \\
\hline Elderly are at high risk of developing COVID-19 complications & $631(94.9)$ & $34(5.1)$ & \\
\hline Children are at high risk of developing COVID-19 complications & $189(28.4)$ & $476(71.6)$ & \\
\hline $\begin{array}{l}\text { People with chronic diseases (hypertension, diabetes, heart disease and respiratory system) are at } \\
\text { high risk of developing COVID-19 complications }\end{array}$ & $614(92.3)$ & $51(7.7)$ & \\
\hline Pregnant women are at high risk of developing COVID-19 complications & $189(27.7)$ & $481(72.3)$ & \\
\hline $\begin{array}{l}\text { People who are immunocompromised (patients receiving chemotherapy, kidneys, and organ-trans- } \\
\text { plant recipients) are at high risk of developing COVID-19 complications }\end{array}$ & $605(91.0)$ & $60(9.0)$ & \\
\hline People who are severely obese are at high risk of developing COVID-19 complications & $80(12.0)$ & $585(88.0)$ & \\
\hline Drinking hot beverages is an optimal method for preventing COVID-19 infection & $294(44.2)$ & $371(55.8)$ & \\
\hline $\begin{array}{l}\text { Non-pharmacological precautions for personal hygiene are an optimal method for preventing } \\
\text { COVID-19 infection }\end{array}$ & $606(91.1)$ & $59(8.9)$ & \\
\hline $\begin{array}{l}\text { Wearing protective masks by healthy people who are not in contact with infected individuals is an } \\
\text { optimal method for preventing COVID-19 infection }\end{array}$ & $263(39.5)$ & $402(60.5)$ & \\
\hline Washing the nose and gargling with water is an optimal method for preventing COVID-19 infection & $369(55.5)$ & $296(44.5)$ & \\
\hline Eating garlic, onions, and pickles is an optimal method for preventing COVID-19 infection & $102(15.3)$ & $563(84.7)$ & \\
\hline Taking antibiotics is an optimal method for preventing COVID-19 infection & $86(12.9)$ & $579(87.1)$ & \\
\hline A vaccine for COVID-19 has been developed and is currently available in global markets & $22(3.3)$ & $533(80.2)$ & $110(16.5)$ \\
\hline COVID-19 is a curable disease & $614(92.3)$ & $14(2.1)$ & $37(5.6)$ \\
\hline Globally, the total mortality rate from COVID-19 infections is less than 5\% & $386(58)$ & $147(22.1)$ & $132(19.8)$ \\
\hline What resources do you rely on to obtain information about COVID-19 and how to prevent it & See Fig. 1 & & \\
\hline
\end{tabular}

\section{Practices}

With regard to the ten positive practices (PP) abided by the individuals for self and others' safety, Table 6 shows that adherence with at least eight practices was observed in 511 (76.8\%) of the respondents; these include washing hands and using proper hygiene (97.0\%), practicing cough etiquette (95.9\%), and avoiding public places and maintaining a safe distance between individuals $(93.5 \%$ and $79.1 \%$ respectively). However, 154 (23.2\%) displayed implementation of at least three negative practices. With regard to smoking habits, respondents reported smoking as follows: less frequently $(5.3 \%)$, same frequency $(6.5 \%)$, more frequently (2.4\%) and cessation (1.8\%). (Fig. 2).

Withh regard to the different variables affecting practices towards COVID-19, and based on data obtained by binary logistic regression as presented in Table 7, numbers showed that females had fewer negative practices compared to males $(\mathrm{OR}=0.323, p<0.001)$. Other factors influencing the respondents' practices were found to be their major and study year. Negative practices were less likely among health professions faculty participants $(\mathrm{OR}=0.631$, 
Fig. 1 Different resources that participants rely on to obtain information about COVID-19 and how to prevent it

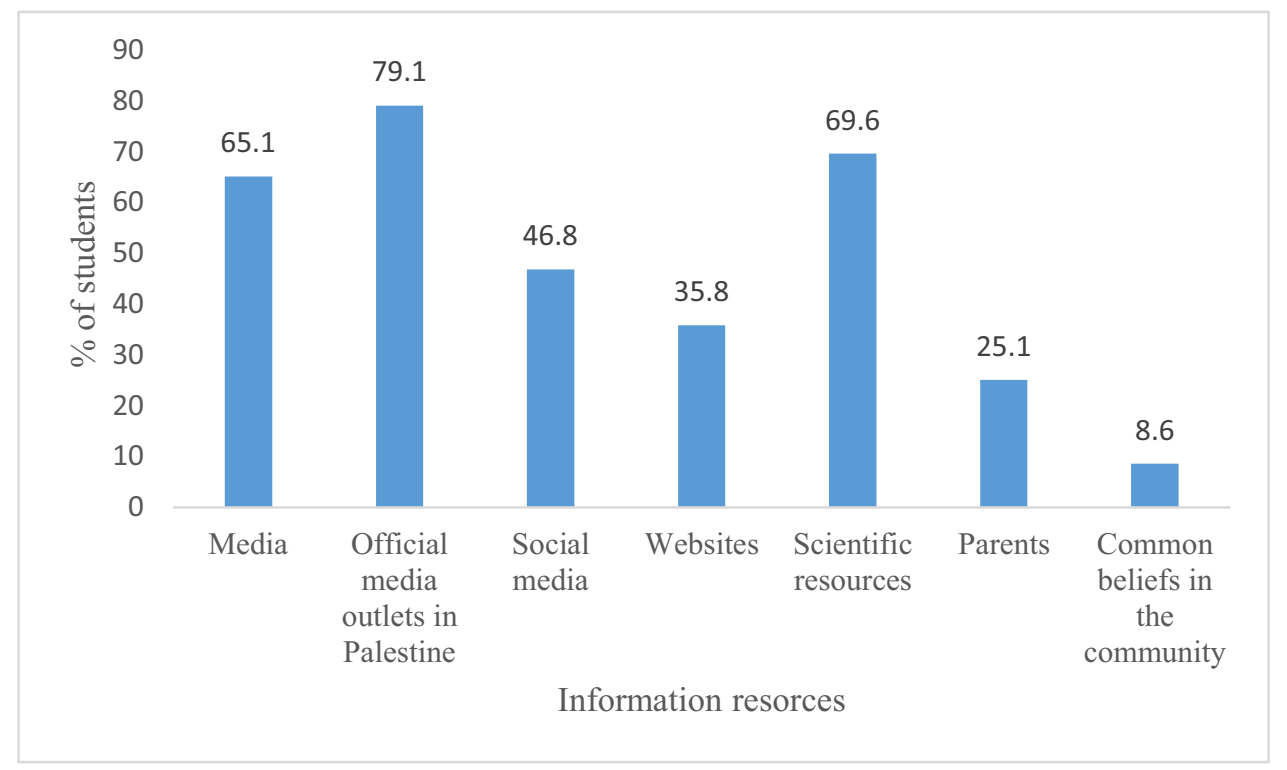

$p=0.083$ ) compared to students from literary faculties, whereas postgraduates tended to have fewer positive practices $(\mathrm{OR}=3.362, p=0.004)$ compared with students in their first year, while no significant differences in practices were found between undergraduates in the other studying years. Moreover, among the variables having an impact on practices was the governorate to which the respondents belong, where middle of the WB revealed the lowest adherence with negative practices $(\mathrm{OR}=0.512, p=0.006)$ compared with students from Jerusalem and the oPT.

\section{Discussion}

Our findings indicate that although less than half of the participants have a good knowledge level with regard to COVID-19, none of the participants was totally unaware of the disease. This could be attributed to conducting the study early in the outbreak in Palestine, and the diverse media coverage of COVID-19 in concurrence with the state of emergency in the country. The relatively low percentage of participants with a good knowledge level in this study is in line with findings of a study conducted among health care workers which reported that knowledge and perceptions of COVID-19 varied across different categories of health care workers but that in general the participants had a poor knowledge level (Bhagavathula et al. 2020a). Nevertheless, the percentage of participants with a good knowledge level is lower than in studies conducted among different segments of the society against MERS (Kharma et al. 2015; Elrggal et al. 2018) and against COVID-19 (Zhong et al. 2020; Wolf et al. 2020; Peng et al. 2020; Zhang et al. 2020a), where the participants have demonstrated good knowledge with regard to transmission, symptoms, and treatment of COVID-19.
The level of knowledge varied depending on the type of question. For example, almost all therespondents knew that COVID-19 is a viral infection that affects the respiratory tract system, and the majority of them knew the methods of transmission and believed that personal hygiene is the optimal method of preventing COVID-19. However, some practices such as drinking hot beverages, gargling with water, and washing the nose were wrongly believed to be preventative. In addition, around an eighth of the participants believed that antibiotics were an optimal method of prevention; more than half of these participants were from literary faculties.

The students from health professions faculties achieved a knowledge level higher than their counterparts'. This could be attributed to these students taking various health-related courses, as well as their involvement in public health campaigns, which in turn enable them to have a better understanding of potentially epidemic infectious diseases such as COVID-19. These findings are consistent with previous studies which reported that students from health colleges had significantly better knowledge than others (Alzoubi et al. 2020; White et al. 2020), and contradict what was concluded in a study conducted in Jordan, where no significant difference between the mean of knowledge, attitude and practice level was found among medical and non-medical students (Alzoubi et al. 2020). In accordance with a study conducted in Uganda (Olum et al. 2020), this study reported that females manifested lower knowledge levels compared to males. Our results are inconsistent with earlier studies which reported that females had a significantly higher score than males (Al-Hazmi et al. 2018; Zhong et al. 2020; Peng et al. 2020), and one study which reported no significant correlation of gender and specialty with both knowledge and attitude (Khan et al. 2020). 
Table 3 Effect of different significant variables on the level of respondents' knowledge; obtained by binary logistic regression (odds ratios and $95 \%$ confidence intervals)

\begin{tabular}{|c|c|c|c|c|c|c|}
\hline Independent variable & & Acceptable KL & Good KL & $P$-value & $\begin{array}{l}\text { Regression } \\
\text { coefficient B }\end{array}$ & OR $(95 \% \mathrm{CI})$ \\
\hline \multirow[t]{2}{*}{ Gender } & Male & $92(52)$ & $85(48)$ & Reference & & \\
\hline & Female & $298(61.1)$ & $190(38.9)$ & 0.01 & 0.53 & $0.588(0.393-0.882)$ \\
\hline \multirow[t]{2}{*}{ Marital status } & Single & $363(58.4)$ & $259(41.6)$ & \multirow{2}{*}{\multicolumn{3}{|c|}{ 0.568: not significant, no regression wasdone }} \\
\hline & Married & $27(62.8)$ & $16(37.2)$ & & & \\
\hline \multirow[t]{3}{*}{ Major } & Literary faculties & $195(72.5)$ & $74(27.5)$ & Reference & & \\
\hline & Scientific faculties & $120(54.5)$ & $100(45.5)$ & 0.004 & 0.610 & $1.841(1.215-2.791)$ \\
\hline & Health professions faculties & $75(42.6)$ & $101(57.4)$ & $P$-value $<0.001$ & 1.242 & $3.462(2.230-5.375)$ \\
\hline \multirow[t]{5}{*}{ Study year } & First & $136(78.2)$ & $38(21.8)$ & Reference & & \\
\hline & Second & $92(54.4)$ & $77(45.6)$ & $P$-value $<0.001$ & 1.0 & $2.717(1.640-4.501)$ \\
\hline & Third & $85(60.3)$ & $56(39.7)$ & 0.003 & 0.811 & $2.249(1.321-3.831)$ \\
\hline & Fourth or more & $56(38.4)$ & $90(61.6)$ & $P$-value $<0.001$ & 1.716 & $5.562(3.275-9.448)$ \\
\hline & Postgraduate & $21(60.0)$ & $14(40.0)$ & 0.166 & 0.602 & $1.826(0.779-4.284)$ \\
\hline \multirow[t]{4}{*}{ Governorate } & Jerusalem and the Pt & $86(61.4)$ & $54(38.6)$ & Reference & & \\
\hline & North of the WB & $48(67.6)$ & $23(42.4)$ & 0.122 & -0.534 & $0.586(0.298-1.154)$ \\
\hline & Middle of the WB & $231(58.2)$ & $166(41.8)$ & 0.245 & 0.269 & $1.308(0.832-2.058)$ \\
\hline & South of the WB & $25(43.9)$ & $32(56.1)$ & 0.244 & 0.419 & $1.520(0.751-3.076)$ \\
\hline \multirow[t]{3}{*}{ Place of residency } & City & $193(58)$ & $140(42)$ & Reference & & \\
\hline & Village & $176(57.3)$ & $131(42.7)$ & 0.331 & 0.190 & $1.210(0.824-1.776)$ \\
\hline & Refugee camps & $84(21)$ & $4(16)$ & 0.016 & -1.448 & $0.235(0.072-0.765)$ \\
\hline \multirow{3}{*}{$\begin{array}{l}\text { Parents completed diploma } \\
\text { or higher educational level }\end{array}$} & None & $143(68.1)$ & 67 (31.9) & Reference & & \\
\hline & One of them & $109(58.6)$ & $77(41.4)$ & 0.132 & 0.365 & $1.440(0.896-2.315)$ \\
\hline & Both & $138(51.3)$ & $131(48.7)$ & 0.013 & 0.658 & $1.931(1.147-3.252)$ \\
\hline \multirow[t]{3}{*}{ Mother's work } & Health sector & $7(28)$ & $18(72)$ & Reference & & \\
\hline & Other sectors & $122(57.0)$ & $92(43.0)$ & 0.03 & -1.104 & $0.332(0.123-0.896)$ \\
\hline & Housewife & $261(61.3)$ & $165(38.7)$ & 0.04 & -1.063 & $0.345(0.125-0.950)$ \\
\hline \multirow[t]{3}{*}{ Father's work } & Health sector & $17(50.0)$ & $17(50.0)$ & \multirow{3}{*}{\multicolumn{3}{|c|}{0.145 not significant, no regression had been done }} \\
\hline & Other sectors & $345(58.3)$ & $247(41.7)$ & & & \\
\hline & Unemployed & $28(71.8)$ & $11(28.2)$ & & & \\
\hline \multirow[t]{2}{*}{ Number of family members } & Six or less & $167(54.2)$ & $141(45.8)$ & Reference & & \\
\hline & More than six & $223(62.5)$ & $134(37.5)$ & 0.128 & -0.279 & $0.757(0.529-1.084)$ \\
\hline \multirow{2}{*}{$\begin{array}{l}\text { Including a family member } \\
\text { over the age of } 60\end{array}$} & Yes & $64(50.8)$ & $62(49.2)$ & Reference & & \\
\hline & No & $326(60.5)$ & $213(39.5)$ & 0.68 & -0.409 & $0.664(0.428-1.030)$ \\
\hline
\end{tabular}

It's noteworthy that despite Facebook being the social media application most used by students in Palestine, official media including the Ministry of Health's website, the Government spokesperson, and the scientific resources were found to be the most important sources of information amongst students. This is attributed to the extremely active media coverage regarding COVID-19 in Palestine, where the official government spokesman and the Minister of Health held two press conferences each day on national TV channels concerning the latest updates about COVID-19 in Palestine, as well as relatable information regarding this disease, such as modes of transmission and preventive instructions during the outbreak. These results are in line with the findings of former studies, which revealed that mass media is the major source of information about COVID-19 and SARS epidemics (Lau et al. 2003; Motta Zanin et al. 2020). However, other previous studies reported that the majority of participants referred to social media in order to obtain information concerning COVID-19, which is relatively inconsistent with our finding (Giao et al. 2020; Bhagavathula et al. 2020b; Abdelhafiz et al. 2020; Saqlain et al. 2020; Aker and Midık 2020). Moreover, $69.6 \%$ of our students reported scientific resources as their source of information, which is due to their easy access to highly recommended medical articles and journals available in the university's library.

Notwithstanding that official media and scientific resources respectively were seen to be the main sources of information in $83.6 \%$ and $81.5 \%$ of students with a good 
Table 4 Students' attitudes toward COVID-19

\begin{tabular}{|c|c|c|c|}
\hline Statement & Agree: $n(\%)$ & Don't agree: $n(\%)$ & Don’t know: $n(\%)$ \\
\hline Are you worried that a family member might get COVID-19? & $603(90.7)$ & $42(6.3)$ & $20(3.0)$ \\
\hline $\begin{array}{l}\text { Do you think that COVID-19 prevention measures should only be applied by older adults } \\
\text { and groups most at risk? }\end{array}$ & $101(15.2)$ & $559(84.1)$ & $5(0.8)$ \\
\hline $\begin{array}{l}\text { In the event that I or a family member develop symptoms of COVID-19 infection, I will } \\
\text { seek advice and assistance from the authorities responsible for providing health services }\end{array}$ & $640(96.2)$ & $8(1.2)$ & $17(2.6)$ \\
\hline My perception of someone will change if they contract COVID-19 & $54(8.1)$ & $571(85.9)$ & $40(6.0)$ \\
\hline $\begin{array}{l}\text { Do you think that the practice of limiting the movement of individuals between countries } \\
\text { and imposing strict quarantine on travelers will limit the transmission and spread of } \\
\text { COVID-19 between individuals? }\end{array}$ & $642(96.5)$ & $13(2.0)$ & $10(1.5)$ \\
\hline $\begin{array}{l}\text { Do you think that the attempts of the local authorities at your place of residence will suc- } \\
\text { ceed in curbing the spread of COVID-19? }\end{array}$ & $442(66.5)$ & $102(15.3)$ & $121(18.2)$ \\
\hline $\begin{array}{l}\text { Do you think that the local authorities have sufficient tools to deal with confirmed and } \\
\text { suspected cases of (COVID-19)? }\end{array}$ & $118(17.7)$ & $397(59.7)$ & $150(22.6)$ \\
\hline $\begin{array}{l}\text { Do you think that the preventative measures that were taken by the Palestinian govern- } \\
\text { ment were early? }\end{array}$ & $267(40.2)$ & $355(53.4)$ & $43(6.5)$ \\
\hline $\begin{array}{l}\text { Do you think that the preventative measures taken by the Palestinian government in the } \\
\text { beginning were sufficient? }\end{array}$ & $348(52.3)$ & $235(35.3)$ & $82(12.3)$ \\
\hline Do you think you are invincible from COVID-19? & $180(27.1)$ & $290(43.6)$ & $195(29.3)$ \\
\hline
\end{tabular}

knowledge level, $57.5 \%$ and $40.7 \%$ of these students also considered media and social media as a source of information. On the other hand, $75.9 \%$ and $70.7 \%$ students with poor knowledge level relied on official media and media respectively as a source of information; furthermore, $61.3 \%$ and $51 \%$ of these students used scientific resources and social media. The difference in information sources contributed to the variety of knowledge levels. Moreover, besides the presented correct and accurate information, unconfirmed information intended to misinform people can also be rapidly disseminated via the media and social media.

With regards to practices, positive and cautious practices with regard to the COVID-19 epidemic were carried out by the vast majority of participants, where $76.8 \%$ of the respondents adhered to at least eight practices out of ten, while only $23.2 \%$ displayed implementation of at least three negative practices. Our findings revealed that more than $90 \%$ of students avoided crowded places, practiced the appropriate methods of coughing and sneezing, washed their hands with soap and water, did not travel between governorates and reduced their presence in public places during the rapid rise period of the COVID-19 outbreak. Furthermore, a high percentage of the students $(79.1 \%)$ maintained a safe distance between them and other people. This is attributed to the good knowledge level about the mode of transmission and the belief that personal hygiene is optimal for prevention from the disease, in addition to strict prevention and control measures implemented by the Palestinian government. We found our results encouraging, since good hygiene practices, behavioral commitment, and social distancing aid in decreasing the transmission rate of COVID-19. These results are comparable with a study performed in China, where the vast majority of the participants held an optimistic attitude with regard to the COVID-19 epidemic (Zhong et al. 2020), and with other studies, where the participants revealed generally adequate positive practices with regard to the COVID19 disease (Truong et al. 2019; Khan et al. 2020; Al Nsour et al. 2020).

Throughout the COVID-19 outbreak, results have shown that two-thirds of participants didn't wear face masks when out in public, while a fifth did not maintain physical distancing. Compliance with the pandemic restrictions is essential and crucial in this phase, and failure to adhere to preventive measures — even if by a minority — would only lead to uncontrolled spreading of the disease. Positive practices with regard to the COVID-19 pandemic were found to be significantly associated with the gender and major of the precipitant. Females were found to have fewer negative practices when compared to males; mainly by avoiding crowded places, practicing coughing and sneezing etiquette, maintaining proper hand hygiene, and avoiding traveling between governorates during the rapid rise of the disease. These findings are in line with other studies which reported association between gender and some positive practices toward COVID19 (Truong et al. 2019; Zhong et al. 2020; Khader et al. 2020). Results have also shown that health-care professions students were more compliant with COVID-19 restrictions than students of other faculties. This is comparable to previous studies which investigated KAP towards COVID-19 among participants from a medical and non-medical study group (Truong et al. 2019; Hussain et al. 2020).

Regarding the attitudes towards COVID-19, the majority of participants were found to be worried that a family member would get COVID-19, and believed that the 
Table 5 Distribution of different students' attitudes and measures with their knowledge level about COVID-19

\begin{tabular}{|c|c|c|c|c|}
\hline Statement & & Acceptable KL: $n(\%)$ & Good KL: $n(\%)$ & $P$-value \\
\hline \multirow[t]{3}{*}{ Are you worried that a family member might get COVID-19? } & Yes & $355(91.0)$ & $248(90.2)$ & \multirow[t]{3}{*}{0.007} \\
\hline & No & $18(4.6)$ & $24(8.7)$ & \\
\hline & Don't know & $17(4.4)$ & $3(1.1)$ & \\
\hline \multirow{3}{*}{$\begin{array}{l}\text { Do you think that COVID-19 prevention measures should only be } \\
\text { applied for older adults and groups most at risk? }\end{array}$} & Yes & $78(20.0)$ & $23(8.4)$ & \multirow[t]{3}{*}{$P$-value $<0.001$} \\
\hline & No & $308(79.0)$ & $251(91.3)$ & \\
\hline & Don't know & $4(1.0)$ & $1(0.4)$ & \\
\hline \multirow{3}{*}{$\begin{array}{l}\text { In the event that I or a family member develop symptoms of COVID- } \\
19 \text { infection, I will seek advice and assistance from the authorities } \\
\text { responsible for providing health services }\end{array}$} & Yes & $376(96.4)$ & $264(96.0)$ & \multirow[t]{3}{*}{0.099} \\
\hline & No & $2(0.5)$ & $6(2.2)$ & \\
\hline & Don't know & $12(3.1)$ & $5(1.8)$ & \\
\hline \multirow[t]{3}{*}{ My perception of someone will change if they contract COVID-19 } & Yes & $41(10.5)$ & $13(4.7)$ & \multirow[t]{3}{*}{0.006} \\
\hline & No & $321(82.3)$ & $250(90.9)$ & \\
\hline & Don't know & $28(7.2)$ & $12(4.4)$ & \\
\hline \multirow{3}{*}{$\begin{array}{l}\text { Do you think that the practice of limiting the movement of individuals } \\
\text { between countries and imposing strict quarantine on travelers will } \\
\text { limit the transmission and spread of COVID-19 between individuals? }\end{array}$} & Yes & $373(95.6)$ & $269(97.8)$ & \multirow[t]{3}{*}{0.301} \\
\hline & No & $10(2.6)$ & $3(1.1)$ & \\
\hline & Don't know & $7(1.8)$ & $3(1.1)$ & \\
\hline \multirow{3}{*}{$\begin{array}{l}\text { Do you think that the attempts of the local authorities at your place of } \\
\text { residence will succeed in curbing the spread of COVID-19? }\end{array}$} & Yes & $258(66.2)$ & $184(66.9)$ & \multirow[t]{3}{*}{0.008} \\
\hline & No & $49(12.6)$ & $53(19.3)$ & \\
\hline & Don't know & $83(21.3)$ & $38(13.8)$ & \\
\hline \multirow{3}{*}{$\begin{array}{l}\text { Do you think that the local authorities have sufficient tools to deal with } \\
\text { confirmed and suspected cases of (COVID-19)? }\end{array}$} & Yes & $75(19.2)$ & $43(15.6)$ & \multirow[t]{3}{*}{0.009} \\
\hline & No & $214(54.9)$ & $183(66.5)$ & \\
\hline & Don't know & $101(25.9)$ & $49(17.8)$ & \\
\hline \multirow{3}{*}{$\begin{array}{l}\text { Do you think that the preventive measures that were taken by the Pales- } \\
\text { tinian government were early? }\end{array}$} & Yes & $152(39.0)$ & $115(41.8)$ & \multirow[t]{3}{*}{0.019} \\
\hline & No & $204(52.3)$ & $151(54.9)$ & \\
\hline & Don't know & $34(8.7)$ & $9(3.3)$ & \\
\hline \multirow{3}{*}{$\begin{array}{l}\text { Do you think that the preventive measures taken by the Palestinian } \\
\text { government in the beginning were sufficient? }\end{array}$} & Yes & $200(51.3)$ & $148(53.8)$ & \multirow[t]{3}{*}{0.015} \\
\hline & No & $130(33.3)$ & $105(38.2)$ & \\
\hline & Don't know & $60(15.4)$ & $22(8.0)$ & \\
\hline \multirow[t]{3}{*}{ Do you think you are invincible from COVID- $9 ?$} & Yes & $124(31.8)$ & $56(20.4)$ & \multirow[t]{3}{*}{ p-value $<0.001$} \\
\hline & No & $134(34.4)$ & $156(56.7)$ & \\
\hline & Don't know & $132(33.8)$ & $63(22.9)$ & \\
\hline
\end{tabular}

prevention measures should be applied by the whole population. This is in line with multiple previous studies in Egypt (Abdelhafiz et al. 2020) and Pakistan (Mirza et al. 2020). Although many studies have reported that a significant percentage of the infected people were young (Chen et al. 2020; Bialek et al. 2020; Escalera-Antezana et al. 2020), our study has shown that less than half of the participants, who are considered young, thought that they can be infected with COVID-19, and nearly one-third thought they were invincible to the disease. Based on the results of the study, a molding of knowledge about COVID-19 into a positive attitude was clearly observed. Interesting differences were noted when comparing students with GKL and AKL, where GKL students tended to be less worried that a family member might get COVID-19, and believed that preventative measures should not be practiced solely by older adults and high risk groups, as compared with AKL students. Furthermore, findings showed that participants with GKL were less likely to find themselves invincible to COVID-19 when compared to those with AKL.

Concerning the performance of the local authorities, two-thirds of participants considered the authorities' attempts successful in controlling the spread of COVID19, and around half of them thought that the preventative measures were sufficient. Furthermore, less than a quarter of the participants believed that local authorities have sufficient tools to deal with the confirmed and suspected cases of COVID-19. These findings disagree with other studies among different communities (Zhong et al. 2020; Rugarabamu et al. 2020; Azlan et al. 2020); this might be due to the lack of economic and medical resources and the shortage within the health system compared to developed countries. 
Table 6 Students' practices with regard to COVID-19

Statement

After the Palestinian government declared a state of emergency, were you committed to washing your hands with soap and water and using disinfectants on a regular basis? (Positive practice)

After the Palestinian government declared a state of emergency, did you practice the proper methods of coughing and sneezing etiquette? (Positive practice)

After the Palestinian government declared a state of emergency, did you wear a face mask when you left the house? (Negative practice)

After the Palestinian government declared a state of emergency, were you in places where people gathered?( Negative practice)

After the Palestinian government declared a state of emergency, did you travel between governorates? (Negative practice)

After the Palestinian government declared a state of emergency, did you reduce your presence in public places and adhere to the state of emergency? (Positive practice)

After the Palestinian government declared a state of emergency, did you maintain a safe distance between you and the individuals around you? (Positive practice)

After the Palestinian government declared a state of emergency, did you supply your home with antipyretics and necessary medications? (Positive practice)

After the Palestinian government declared a state of emergency, did you supply your home with vitamins and nutritional supplements? (Positive practice)

After the Palestinian government declared a state of emergency, were your smoking habits affected by the emerging Corona virus (COVID-19)?
Often or more: $n(\%) \quad$ Rarely or less: $n(\%)$

645 (97.0)

$20(3.0)$

$638(95.9)$

$204(30.7)$

$461(69.3)$

$38(5.7)$

$627(94.3)$

$23(3.5)$

$622(93.5)$

$526(79.1)$

$363(54.6)$

$365(54.9)$

$300(45.1)$

See Fig. 2
Fig. 2 The way smoking habits were affected for respondents during the Covid-19 emergency period

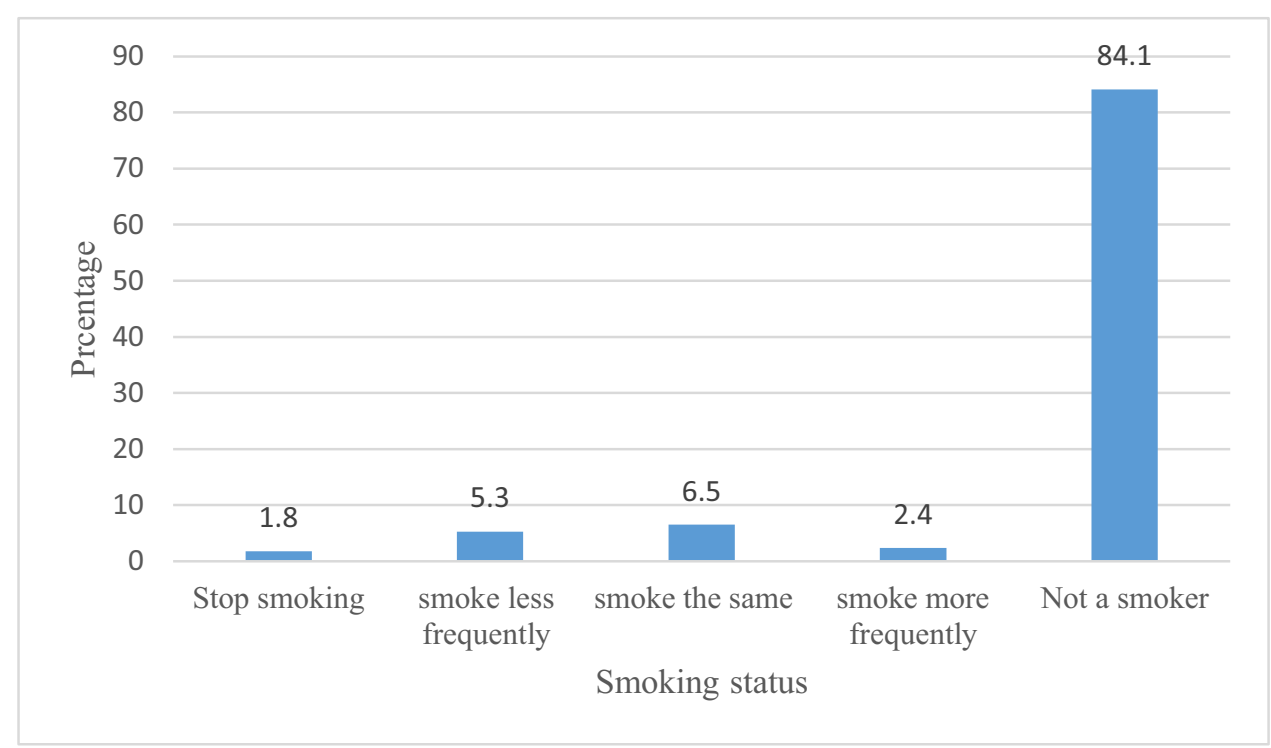

\section{Conclusion}

Our results revealed that students had variable knowledge regarding COVID-19, and the majority depended on the official media briefs in Palestine as a source of information, thus reflecting the need of collaborative efforts between the Ministry of Health and the media to implement more effective tools that increase the knowledge level about COVID-19 and the preventive measures needing to be followed among the community, especially that the protective measures were more adhered by health profession students, which may reveal that an increase in community knowledge would increase their commitment to the preventive measures. With regard to practices, positive and cautious practices with regard to the COVID-19 papidemic were carried out by the vast majority of participants. Positive practices with regard to the COVID-19 pandemic were found to be significantly associated with gender, where females were found to have fewer negative practices when compared to males. Furthermore, the majority of respondents were worried that a family member might get infected 
Table 7 Effect of different significant variables on positive practices of respondents obtained by binary logistic regression (odds ratios and 95\% confidence intervals)

\begin{tabular}{|c|c|c|c|c|c|c|}
\hline Independent variable & & $\begin{array}{l}\text { More PP: } \\
n(\%)\end{array}$ & $\begin{array}{l}\text { Less PP: } \\
n(\%)\end{array}$ & $P$-value & $\begin{array}{l}\text { Regression } \\
\text { coefficient } \\
\text { B }\end{array}$ & OR $(95 \% \mathrm{CI})$ \\
\hline \multirow[t]{2}{*}{ Gender } & Male & $107(60.5)$ & $70(39.5)$ & Reference & & \\
\hline & Female & $404(82.8)$ & $84(17.2)$ & $P$-value $<0.001$ & -1.130 & $0.323(0.212-0.491)$ \\
\hline \multirow[t]{3}{*}{ Major } & Literary faculties & $201(74.7)$ & $68(25.3)$ & Reference & & \\
\hline & Scientific faculties & $163(74.1)$ & $57(25.9)$ & 0.834 & -0.048 & $0.953(0.607-1.497)$ \\
\hline & $\begin{array}{l}\text { Health professions facul- } \\
\text { ties }\end{array}$ & $147(83.5)$ & $29(16.5)$ & 0.083 & -0.461 & $0.631(0.375-1.062)$ \\
\hline \multirow[t]{5}{*}{ Study year } & First & $136(78.2)$ & $38(21.8)$ & Reference & & \\
\hline & Second & $135(79.9)$ & $34(20.1)$ & 0.567 & -0.162 & $0.850(0.488-1.481)$ \\
\hline & Third & $105(74.5)$ & $36(25.5)$ & 0.754 & 0.089 & $1.094(0.625-1.912)$ \\
\hline & Fourth or more & $117(80.1)$ & $29(19.9)$ & 0.378 & -0.259 & $0.771(0.433-1.374)$ \\
\hline & Postgraduate & $18(51.4)$ & 17 (48.6) & 0.004 & 1.213 & $3.362(1.458-7.755)$ \\
\hline \multirow[t]{4}{*}{ Governorate } & Jerusalem and the oPt & 99 (70.7) & $41(29.3)$ & Reference & & \\
\hline & North of the WB & $47(66.2)$ & $24(33.8)$ & 0.849 & -0.065 & $0.937(0.480-1.830)$ \\
\hline & Middle of the WB & $322(81.1)$ & $75(18.9)$ & 0.006 & -0.669 & $0.512(0.317-0.828)$ \\
\hline & South of the WB & $43(75.4)$ & $14(24.6)$ & 0.144 & -0.583 & $0.558(0.255-1.221)$ \\
\hline \multirow[t]{3}{*}{ Place of residency } & City & $257(77.2)$ & $76(22.8)$ & \multirow{3}{*}{\multicolumn{3}{|c|}{0.298 not significant, no regression had done }} \\
\hline & Village & $238(77.5)$ & $69(22.5)$ & & & \\
\hline & Refugee camps & $16(64.0)$ & $9(36.0)$ & & & \\
\hline \multirow{3}{*}{$\begin{array}{l}\text { Parents completed } \\
\text { diploma or higher educa- } \\
\text { tional level }\end{array}$} & None & $160(76.2)$ & $50(23.8)$ & \multirow{3}{*}{\multicolumn{3}{|c|}{0.577 not significant, no regression had been done }} \\
\hline & One of them & 139 (74.7) & $47(25.3)$ & & & \\
\hline & Both & $212(78.8)$ & $57(21.2)$ & & & \\
\hline \multirow[t]{3}{*}{ Mother's work } & Health sector & $19(76.0)$ & $6(24.0)$ & \multirow{3}{*}{\multicolumn{3}{|c|}{0.329 not significant, no regression had been done }} \\
\hline & Other sectors & $172(80.4)$ & $42(19.6)$ & & & \\
\hline & Housewife & $320(75.1)$ & $106(24.9)$ & & & \\
\hline \multirow[t]{3}{*}{ Father's work } & Health sector & $27(79.4)$ & $7(20.6)$ & \multirow{3}{*}{\multicolumn{3}{|c|}{0.146 not significant, no regression had been done }} \\
\hline & Other sectors & $459(77.5)$ & $133(22.5)$ & & & \\
\hline & Unemployed & $25(64.1)$ & $14(35.9)$ & & & \\
\hline \multirow{2}{*}{$\begin{array}{l}\text { Number of family mem- } \\
\text { bers }\end{array}$} & Six or less & $234(76.0)$ & $74(24.0)$ & \multirow{2}{*}{\multicolumn{3}{|c|}{0.622 not significant, no regression had been done }} \\
\hline & More than six & $277(77.6)$ & $80(22.4)$ & & & \\
\hline \multirow{2}{*}{$\begin{array}{l}\text { Including a family mem- } \\
\text { bers over the age of } 60\end{array}$} & Yes & $91(72.2)$ & $35(27.8)$ & \multirow{2}{*}{\multicolumn{3}{|c|}{0.172 not significant, no regression had been done }} \\
\hline & No & $420(77.9)$ & $119(22.1)$ & & & \\
\hline \multirow[t]{2}{*}{ Knowledge level } & Acceptable & $294(75.4)$ & $96(24.6)$ & \multirow{2}{*}{\multicolumn{3}{|c|}{0.289 not significant, no regression had been done }} \\
\hline & Good & $217(78.9)$ & $58(21.1)$ & & & \\
\hline
\end{tabular}

with the virus, and considered the preventative measures taken by the Palestinian government at the beginning were sufficient and implemented in a timely manner.

\section{Limitations of the study}

The study has potential limitations to be noted. Above all, the participants of the study were students, and this sample of participants is unlikely to be representative of the general Palestinian population. Also, the study participants volunteered to participate in the study (self-selection bias), thus limiting the generalizability of the study findings. Moreover, the collected data was self-reported and depended on the participants' integrity and recall ability, and thus might be subject to recall bias. Taking all the above-mentioned limitations into consideration, more studies should be conducted in the future to evaluate the knowledge, practices, and attitudes toward COVID-19 among different groups of society.

Acknowledgements We would like to express our appreciation to the Professors at the Faculty of Pharmacy, Nursing and Health Professions, Birzeit University, Palestine, for their support, and express an honest thank you to all students of Birzeit University who participated in the survey. 
Authors' contributions All authors contributed to the study conception and design. Material preparation and supervision were performed by Hani A. Naseef. Data analysis were performed by Hani A. Naseef and Ni'meh A. Al-Shami. All authors contributed in writing the first draft of the manuscript and commented on previous versions of the manuscript. All authors read and approved the final manuscript.

Data availability The data used to support the findings of this study are available from the corresponding author upon request.

Code availability Not applicable.

\section{Declarations}

Ethics approval The study was approved by the IRB committee at Faculty of Pharmacy, Nursing and Health Professions, Birzeit University with reference number BZU- PNH- 2006.

Consent to participate - We confirm the confidentiality of each participant's answer, and the data will be treated with complete confidentiality, and only for research and statistical purposes only.

- We confirm that their participation in the study is voluntary, with no financial compensation.

- We confirm the participants' right to not answer any question they do not want to, and their right to withdraw from the study at any time they wish without giving reasons without no negative consequences being applied to them.

- Written consent was obtained from each participant before their participation in the study.

Consent for publication The corresponding author confirms that the manuscript has been read and approved for submission by all the named authors.

Conflict of interest The authors state that they do not present any conflict of interests in the present research.

\section{References}

Abdelhafiz AS, Mohammed Z, Ibrahim ME, et al (2020) Knowledge, perceptions, and attitude of Egyptians towards the novel coronavirus disease (COVID-19). J Community Health 45(5):881890https://doi.org/10.1007/s10900-020-00827-7

Aker S, Mıdık Ö (2020) The views of medical faculty students in Turkey concerning the COVID-19 pandemic. J Community Health 5(4):684-688. https://doi.org/10.1007/s10900-020-00841-9

Al-Hazmi A, Gosadi I, Somily A et al (2018) Knowledge, attitude and practice of secondary schools and university students toward Middle East Respiratory Syndrome epidemic in Saudi Arabia: a cross-sectional study. Saudi J Biol Sci 25:572-577. https://doi. org/10.1016/j.sjbs.2016.01.032

Al Nsour M, Khader Y, Al Serouri A et al (2020) Awareness and preparedness of Field Epidemiology Training Program graduates in the Eastern Mediterranean Region to respond to COVID-19: a cross-section study. JMIR Med Educ 6(1):e19047. https://doi.org/ $10.2196 / 19047$

Alzoubi H, Alnawaiseh N, Al-Mnayyis A et al (2020) Covid-19 Knowledge, attitude and practice among medical and non-medical university students in Jordan. J Pure Appl Microbiol 14:17-24. https://doi.org/10.22207/JPAM.14.1.04
Arora C, Sinha B, Malhotra A, Ranjan P (2017) Development and validation of health education tools and evaluation questionnaires for improving patient care in lifestyle related diseases. $\mathbf{J}$ Clin Diagn Res 11:JE06

Asaad AM, El-Sokkary RH, Aedh AI et al (2019) Exploring knowledge and attitude toward Middle East Respiratory Syndromecoronavirus (MERS-coV) among university health colleges' students, Saudi Arabia: a cross-sectional study. Am J Infect Dis 15:37-43. https://doi.org/10.3844/ajidsp.2019.37.43

Azlan AA, Hamzah MR, Sern TJ et al (2020) Public knowledge, attitudes and practices towards COVID-19: a cross-sectional study in Malaysia. PLoS ONE 15:e0233668. https://doi.org/10. 1371/journal.pone.0233668

Bener A, Al-Khal A (2004) Knowledge, attitude and practice towards SARS. J R Soc Promot Health 124:167-170. https://doi.org/10. 1177/146642400412400408

Bhagavathula AS, Aldhaleei WA, Rahmani J et al (2020a) Knowledge and perceptions of COVID-19 among health care workers: cross-sectional study. JMIR Public Health Surveill 6:e19160. https://doi.org/10.2196/19160

Bhagavathula AS, Aldhaleei WA, Rahmani J et al (2020b) Novel Coronavirus (COVID-19) Knowledge and perceptions: a survey of healthcare workers. medRxiv 2020.03.09.20033381. https:// doi.org/10.1101/2020.03.09.20033381

Bialek S, Boundy E, Bowen V et al (2020) Severe outcomes among patients with coronavirus disease 2019 (COVID-19) - United States, February 12-March 16, 2020. MMWR Morb Mortal Wkly Rep 69:343-346. https://doi.org/10.15585/mmwr.mm691 $2 \mathrm{e} 2$

CDC (n.d.) Coronavirus Disease 2019 (COVID-19) I CDC. Centers for Disease Control and Prevention, Atlanta, GA. https://www. cdc.gov/coronavirus/2019-ncov/index.html. Accessed 4 June 2020

Chen N, Zhou M, Dong X et al (2020) Epidemiological and clinical characteristics of 99 cases of 2019 novel coronavirus pneumonia in Wuhan, China: a descriptive study. www.thelancet.com 395:507. https://doi.org/10.1016/S0140-6736(20)30211-7

ECDC (2020a) Novel coronavirus disease 2019 (COVID-19) pandemic: increased transmission in the EU/EEA and the UK sixth update. European Centre for Disease Prevention and Control, Stockholm

ECDC (2020b) ECDC COVID-19 pandemic. European Centre for Disease Prevention and Control, Stockholmhttps://www.ecdc.europa. eu/en/covid-19-pandemic. Accessed 8 Sept 2020

Elrggal ME, Karami NA, Rafea B et al (2018) Evaluation of preparedness of healthcare student volunteers against Middle East Respiratory Syndrome coronavirus (MERS-CoV) in Makkah, Saudi Arabia: a cross-sectional study. J Public Health (Germany) 26:607-612. https://doi.org/10.1007/s10389-018-0917-5

Escalera-Antezana JP, Lizon-Ferrufino NF, Maldonado-Alanoca A et al (2020) Clinical features of cases and a cluster of coronavirus disease 2019 (COVID-19) in Bolivia imported from Italy and Spain. Travel Med Infect Dis 35:101653. https://doi.org/10.1016/j.tmaid. 2020.101653

Giao H, Le An P, Thi Ngoc Han N et al (2020) Knowledge and attitude toward COVID-19 among healthcare workers at District 2 Hospital, Ho Chi Minh City. Asian Pac J Trop Med 13:6-11. https:// doi.org/10.4103/1995-7645.280396

Goni MD, Hasan H, Naing NN et al (2019) Assessment of knowledge, attitude and practice towards prevention of respiratory tract infections among Hajj and Umrah pilgrims from Malaysia in 2018. Int J Environ Res Public Health 16(22):4569. https://doi.org/10. 3390/ijerph16224569

Hussain A, Garima T, Singh BM et al (2020) Knowledge, attitudes, and practices towards COVID-19 among Nepalese residents: a quick online cross-sectional survey. Asian J Med Sci 11:6-11. https:// doi.org/10.3126/ajms.v11i3.28485 
Ishii H, Shimatsu A, Okimura Y et al (2012) Development and validation of a new questionnaire assessing quality of life in adults with hypopituitarism: Adult Hypopituitarism Questionnaire (AHQ). PLoS ONE 7:e44304. https://doi.org/10.1371/journal.pone.00443 04

Khader Y, Al Nsour M, Al-Batayneh OB et al (2020) Dentists' awareness, perception, and attitude regarding COVID-19 and infection control: cross-sectional study among Jordanian dentists. JMIR Public Health Surveill 6:e18798. https://doi.org/10.2196/18798

Kharma M, Amer M, Tarakji B et al (2015) Assessment of the awareness level of dental students toward Middle East Respiratory Syndrome-coronavirus. J Int Soc Prev Community Dent 5:163. https://doi.org/10.4103/2231-0762.159951

Kim CJ, Choi WS, Jung Y et al (2016) Surveillance of the Middle East respiratory syndrome (MERS) coronavirus (CoV) infection in healthcare workers after contact with confirmed MERS patients: incidence and risk factors of MERS-CoV seropositivity. Clin Microbiol Infect 22:880-886. https://doi.org/10.1016/j.cmi. 2016.07.017

Lau JTF, Yang X, Tsui H, Kim JH (2003) Monitoring community responses to the SARS epidemic in Hong Kong: from day 10 to day 62. J Epidemiol Community Health 57:864-870

Mbroh LA (2019) Assessing knowledge, attitude and practices of hand hygiene among university students. All theses,dissertations, and other capstone projects 950. Minnesota State University, Mankato, MN

Mirza TM, Ali R, Khan HM (2020) The knowledge and perception of COVID-19 and its preventive measures, in public of Pakistan. Pak Armed Forces Med J 70:338-345

Motta Zanin G, Gentile E, Parisi A, Spasiano D (2020) A preliminary evaluation of the public risk perception related to the COVID19 health emergency in Italy. Int J Environ Res Public Health 17:3024. https://doi.org/10.3390/ijerph17093024

Kahn AM, Nawabi S, Javed MQ (2020) Dental faculty's knowledge and attitude regarding COVID-19 disease in Qassim, Saudi Arabia. Research Square preprint. https://doi.org/10.21203/RS.3. RS-25306/V1

Epidemiology Working Group for NCIP Epidemic Response, Chinese Center for Disease Control and Prevention (2020) [The epidemiological characteristics of an outbreak of 2019 novel coronavirus diseases (COVID-19) in China]. Zhonghua Liu Xing Bing Xue Za Zhi41:145-151. (Article in Chinese). https://doi.org/10.3760/ cma.j.issn.0254-6450.2020.02.003

Olum R, Chekwech G, Wekha G et al (2020) Coronavirus Disease-2019: knowledge, attitude, and practices of health care workers at Makerere University Teaching Hospitals, Uganda. Front Public Health 8:181. https://doi.org/10.3389/fpubh.2020.00181

Peng Y, Pei C, Zheng Y, et al (2020) A cross-sectional survey of knowledge, attitude and practice associated with COVID-19 among undergraduate students in China. BMC Public Health 20:1292. https://doi.org/10.21203/rs.3.rs-21185/v1

Raosoft (2020) Sample Size Calculator by Raosoft, Inc. Raosoft Inc., Seattle, WAhttp://www.raosoft.com/samplesize.html. Accessed 3 Apr 2020

Rugarabamu S, Byanaku A, Ibrahim M (2020) Knowledge, attitudes, and practices (KAP) towards COVID-19: a quick online cross-sectional survey among Tanzanian residents. medRxiv 2020.04.26.20080820. https://doi.org/10.1101/2020.04.26.20080 820

Saqlain M, Munir MM, urRehman S et al (2020) Knowledge, attitude, practice and perceived barriers among healthcare professionals regarding COVID-19: a cross-sectional survey from Pakistan. J
Hosp Infect 105(3):419-423. https://doi.org/10.1016/j.jhin.2020. 05.007

Truong TNK, Vo TQ, Nguyen NH, et al (2019) Knowledge, attitudes, and practices among university students in relation to dengue fever: A multi-center study across Vietnamese regions. J Pak Med Assoc69(Suppl 2)(6):S95-S107

Wang D, Hu B, Hu C et al (2020) Clinical characteristics of 138 hospitalized patients with 2019 novel coronavirus-infected pneumonia in Wuhan, China. JAMA 323(11):1061-1069. https://doi.org/10. 1001/jama.2020.1585

White MS, Omer DM, Mohammad DGN (2020) Knowledge, attitude and practice on prevention of airborne and droplet infections during the outbreak of corona virus among the college students in University of Bisha, Saudi Arabia. Int J Contemp Res Rev 11:20773-20776. https://doi.org/10.15520/IJCRR.V11I04.802

WHO/Europe (2020) WHO announces COVID-19 outbreak a pandemic. WHO, Geneva. https://www.euro.who.int/en/health-topics/health-emergencies/coronavirus-covid-19/news/news/2020/3/ who-announces-covid-19-outbreak-a-pandemic. Accessed 8 Sep 2020

WHO (2020a) Coronavirus disease (COVID-19) Situation Report 155. WHO, Geneva.

WHO (2020b) Questions and answers I COVID-19 | Health topics. WHO, Geneva. http://www.emro.who.int/health-topics/coronavirus/questions-and-answers.html. Accessed 3 Apr 2020b

WHO (2020c) Q\&A on coronaviruses (COVID-19). WHO, Geneva. https://www.who.int/emergencies/diseases/novel-coronavirus2019/question-and-answers-hub/q-a-detail/q-a-coronaviruses. Accessed 8 Sep 2020

Wolf MS, Serper M, Opsasnick L, et al (2020) Awareness, attitudes, and actions related to COVID-19 among adults with chronic conditions at the onset of the U.S. outbreak. Ann Int Med 173(2):100 109. https://doi.org/10.7326/m20-1239

World Health Organization (2020) Coronavirus disease 2019 (COVID19) Situation Report - 91. WHO, Geneva. https://www.who.int/ docs/default-source/coronaviruse/situation-reports/20200420sitrep-91-covid-19.pdf?sfvrsn=fcf0670b_4. Accessed 8 May 2020

Yang S, Cho SI (2017) Middle East respiratory syndrome risk perception among students at a university in South Korea, 2015. Am J Infect Control 45:e53-e60. https://doi.org/10.1016/j.ajic.2017. 02.013

Zhang M, Zhou M, Tang F et al (2020a) Knowledge, attitude, and practice regarding COVID-19 among healthcare workers in Henan, China. J Hosp Infect 105:183-187. https://doi.org/10.1016/j.jhin. 2020.04.012

Zhang W, Zhao Y, Zhang F et al (2020b) The use of anti-inflammatory drugs in the treatment of people with severe coronavirus disease 2019 (COVID-19): The perspectives of clinical immunologists from China. Clin Immunol 214:108393. https://doi.org/10.1016/j. clim.2020.108393

Zhong BL, Luo W, Li HM et al (2020) Knowledge, attitudes, and practices towards COVID-19 among chinese residents during the rapid rise period of the COVID-19 outbreak: a quick online crosssectional survey. Int J Biol Sci 16:1745-1752. https://doi.org/10. $7150 /$ ijbs. 45221

Publisher's note Springer Nature remains neutral with regard to jurisdictional claims in published maps and institutional affiliations. 